\title{
Pengaruh Penggunaan Media Teka-Teki Silang (TTS) Terhadap Hasil Belajar Siswa pada Pelajaran IPS Kelas V
}

\author{
Prima Rias Wana \\ Pendidikan Guru Sekolah Dasar, STKIP Modern Ngawi, premiumpower21@ gmail.com
}

\begin{abstract}
Abstrak
Penelitian ini berjudul Pengaruh Penggunaan Media Teka-Teki Silang (TTS) Terhadap Prestasi Belajar IPS Siswa Kelas V SDN Karangbanyu 03 Widodaren, memiliki tujuan agar mengetahui perbedaan prestasi belajar siswa sesudah diberi perlakuan (treatment) pada saat post-test dan sebelum diberi perlakuan (treatment). Banyak hal yang mempengaruhi prestasi belajar siswa salah satunya adalah penggunaan media Teka-Teki Silang (TTS).Penelitian yang digunakan adalah jenis penelitian kuantitatif eksperimen semu serta menggunakan desain Quasy Eksperimen, bentuk desain Quasy Eksperimen yang gunakan adalah Nonequivalent Control Group. Selanjutnya menjadi objek dalam penelitian ini adalah siswa kelas 5A menjadi eksperimen dengan jumlah 33 siswa dan kelas VC menjadi kelas kontrol dengan jumlah 38 siswa. Data dari hasil belajar siswa diperoleh post-test berbentuk pilihan ganda. Penelitian ini menunjukkan hasil perbedaan dari data hasil belajar sebesar 75,51 untuk kelas eksperimen, dan 66,44 untuk kelas kontrol. Hasil penelitian menunjukkan bahwa ada peningkatan hasil belajar siswa yang menggunakan media Teka-Teki Silang (TTS). Hasil penelitian menunjukkan bahwa media Teka-Teki Silang (TTS) dapat dijadikan sebagai alternatif media belajar siswa pada terutama mata pelajaran IPS.
\end{abstract}

Kata kunci: Media, teka-teki silang, (TTS), hasil belajar , pembelajaran

\section{PENDAHULUAN}

Sumber daya manusia (SDM) yang berkualitas sangat berkaitan erat dengan pendidikan. Pendidikan juga berperan penting demi keberlangsungan kehidupan bangsa. Begitu pula di Indonesia pendidikan merupakan sektor paling utama untuk bidang Nasional. Hal ini dikarenakan melalui sektor pendidikan dapat dibentuk sumber daya manusia (SDM) yang berkualitas dan mumpuni, seperti yang dicantumkan dalam Undang-Undang No. 20 Tahun 2003 BAB II Pasal 3 bahwa:

"Pendidikan Nasional berfungsi
mengembangkan kemampuan dan
membentuk watak seperti peradaban
bangsa yang bermartabat dalam rangka
mencerdaskan kehidupan bangsa,
bertujuan untuk berkembangnya potensi
peserta didik agar menjadi manusia yang
beriman dan bertaqwa kepada Tuhan

Yang Maha Esa, berakhlak mulia, sehat, berilmu, cakap, kreatif, mandiri, menjadi warga Negara yang demokratis dan bertanggungjawab."

Dalam penyelenggaraan pendidikan di Sekolah Dasar, perlunya inovasi guru dalam pelaksanaan pembelajaran. Inovasi yang digunakan mampu mempengaruhi prestasi anak terutama pada mata pelajaran IPS. Menurut Ahmad Susanto (2013, ;137) mengemukakan bahwa :

"Hakikat IPS adalah harapan untuk mampu membina suatu masyarakat yang baik dimana anggotanya benar-benar berkembang sebagai insan sosial yang rasional dan penuh tanggungjawab,sehingga oleh karenanya diciptakan nilai-nilai”.

Tujuan utama dari IPS adalah memberikan pemahman tentang konsep pemikiran yang 
berdasarkan keadaan realita kondisi sosial dilingkungan siswa. Sehingga dengan menggunakan pendidikan IPS sebagai upaya peningkatan kualitas pendidikan khususnya kualitas sumber daya manusia. Namun pada kenyataannya masih banyak yang memandang rendah tentang pembelajaran dan pendidikan IPS kurang memiliki peranan penting dalam kehidupan sosial. Selain itu dianggap sebagai pembelajaran yang membosankan, sehingga prestasi belajar IPS siswa berada di bawah ratarata dan mengakibatkan mutu pendidikan IPS sangatlah rendah.

Pembelajaran IPS salah satu pembelajaran yang dapat memberikan pengalaman langsung kepada siswa. dengan mengaitkan kenyataan atau keadaan secara langsung. Banyak faktor yang mempengaruhi tercapai tidaknya pembelajaran IPS. Faktor tersebut berasal dari guru, siswa, lingkungan sekolah, lingkungan masyarakat dan hal-hal lain yang berhubungan dengan berhasil tidaknya pembelajaran IPS.

Fenomena yang ada di SDN Karangbanyu 03 penyebab terjadinya pembelajaran rendah dikarenakan faktor pembelajaran yang bersifat monoton. Sehingga anak-anak merasa jenuh dan mempengaruhi prestasi belajar mereka. Dapat diketahui dari hasil wawancara dengan salah satu siswa ketika peneliti bertanya bagaimana pendapatnya mengenai pembelajaran IPS? siswa tersebut menjawab bahwa pembelajaran IPS adalah pembelajaran yang sulit untuk dipahami, banyak sejarah yang harus dihafalkan dan diingat, ngantuk dan membosankan.

Rendahnya minat belajar IPS siswa ini membuat peneliti cukup merasa khawatir karena bagaimanapun juga minat belajar siswa sangat mempengaruhi prestasi belajar IPS siswa. Prestasi belajar siswa dipengaruhi oleh faktor interal dan faktor eksternal. Faktor eksternal merupakan faktor yang dianggap sangat mempengaruhi kehidupan seseorang. Faktor eksternal juga mempengaruhi prosesdan hasi belajar. Dalam hal ini siswa merasa kurang tertarik terhadap pelajaran IPS. siswa yang terlibat dalam penelitian ini adalah siswa kelas V dengan materi IPS Penjajahan masa Belanda dan Jepang. Mereka menganggap bahwa materi IPS yang berkaitan dengan sejarah bersifat membosankan. Sehingga prestasi belajar IPS mereka rendah.

Sebagai alternatif solusi dari permasalahan itu yaitu dengan memakai sarana media pembelajaran. Sarana media pembelajaran digunakan untuk merangsang minat dalam belajar siswa sehingga dapat mengembangkan kompetensi siswa baik dalam ranah kognitif, afektif dan psikomotorik. Salah satu media pembelajaran yang digunakan adalah media Teka-Teki Silang (TTS). Media yang dibuat dengan bentuk kotak-kotak secara vertikal dan horizontal. Peneliti menyediakan bebrapa pertanyaan terkait materi yang akan disampaikan. Setelah itu siswa akan enjawab pertanyaan terebut dengan cara mengisi kotakkotak yang telah disediakan. Antara jawaban satu dengan yang lainnya akan berkesinambungan, sehingga jawaban yang diiisi oleh siswa mampu untuk mengasah kemampuan otak siswa. Media Teka-Teki Silang (TTS) akan dikerjakan secara individu dan kelompok. Aturan main untuk .media secara berkelompok dikerjakan bersama-sama dengan teman yang telah di tentuka.n. kelompok yang terdahulu mengisi Teka-Teki Silang (TTS) maka dianggap sebagai pemenangnya.

Media pembelajaran ini merupakan salah satu media yang baik dan menyenangkan. Menurut Hisyam, dkk. (2007) dalam Sri dan Zakir (2017, ;45) mengungkapkan bahwa keunggulan dari media Teka-Teki Silang (TTS) adalah:

1. Dapat merangsang siswa lebih aktif

2. Dapat mengembangkan kemandirian siswa 
3. Dapat memperdalam pemahaman siswa dalam belajar

4. Membina tanggungjawab dan disiplin siswa

5. Adanya persaingan sehat antar siswa

6. Hasil belajar lebih tahan lama

Selain itu adapun kelemahan media TekaTeki Silang (TTS), antara lain :

1. Kata-kata yang terbentuk pendek.

2. Permainan yang seru membuat suasana menjadi gaduh, hal ini dapat memicu terganggunya kelas yang lain.

3. Untuk mengisi kotak yang saling berkaitan membutuhkan kosakata yang lebih banyak.

Dalam penelitian yang dilakukan oleh Syakroni yang berjudul Penerapan Model Pembelajaran Kooperatif Tipe TTS untuk Meningkatkan Minat Belajar IPS Siswa Kelas VIII SMP Negeri 4 Tanah Putih mendapatkan hasil bahwa minat belajar IPS siswa kelas VII SMP Negeri 4 Tanah Putih mengalami peningkatan yang signifikan. Selain dari minat belajar penggunaan media TTS ini juga meningkatkan aktifitas pada guru dan siswa dalam proses pembelajaran. Peneliti ini sangat menganjurkan untuk menerapkannya dalam pembelajaran karena selain meningkatkan minat belajar siswa juga meningkatkan aktifitas belajar baik dari guru maupun siswa.

Selain itu media ini dapat menciptakan partisipasi anak yang lebih aktif terlibat ke dalam kegiatan pembelajaran. Dengan menggunakan atau memakai media Teka-Teki Silang (TTS) diharapkan mampu memberi pengaruh positif dalam prestasi belajar IPS siswa di SDN Karangbanyu 03.

\section{METODE}

\section{Rancangan Penelitian}

M. Toha Anggoro, dkk. (2011a, ;1.1) mengatakan bahwa "penelitian diartikan sebagai proses mengumpulkan data dan menganalisis data atau informasi secara sistematis sehingga menghasilkan kesimpulan yang sah". Dalam penelitian ini penulis memakai jenis penelitian kuantitatif. Penelitian kuantitatif ini dinggunakan untuk menguji satu teori, mendeskripsikan statistik untuk menyajikan fakta atau, untuk menunjukkan hubungan antara variable dan ada juga yang bersifat mengembangkan konsep. Sedangkan metode yang digunakan adalah metode eksperimen, yaitu metode eksperimen menurut Sugiyono (2011a, ;6) merupakan "metode yang digunakan untuk mencari pengaruh treatment (perlakuan) tertentu".

Tujuan utama dari penelitian ini adalah untuk mengukur ada tidaknya pengaruh dengan cara menyediakan kelas kontrol dan memberikan perlakuan tertentu pada kelas eksperimen. Pembelajaran pada kelas ekperimen memperoleh perlakuan dengan memakai media Teka-Teki Silang (TTS). Sedangkan kelas kontrol tidak mendapatkan perlakuan pembelajaran dengan media TekaTeki Silang (TTS). Di akhir kegiatan pembelajaran siswa akan diberi soal post-test yaitu dengan memberikan tes kemampuan penyelesaiaan soal yaitu bentuk tes item pilihan ganda yang diberlakukan pada kedua kelas sampel dengan item soal tes yang sama untuk mengetahui prestasi belajar siswa.

\section{Populasi dan Sampel}

Sugiyono (2011b, ;80) mengungkapkan obyek dan subyek yang mempunyai kualitas serta karakteristik yang ditetapkan oleh peneliti untuk dipelajari dan kemudian di tarik kesimpulannya merupakan populasi merupakan wilayah generalisasi. Selanjutnya M. Toha Anggoro, dkk. ( 2011b, ;4.2) menyatakan populasi adalah sesuatu himpunan lengkap dari satuan-satuan individu yang karakteritiknya ingin kita ketahui. Populasi dalam penelitian ini adalah seluruh siswakelas VA dan VB SDN Karangbanyu 03.

Sampel adalah bagian dari karakteristik dan jumlah yang dimiliki oleh populasi tersebut. 
Apabila subyeknya tidak ada atau kurang dari 100, lebih baik diambil semua sehingga bisa dikatakan penelitiannya merupakan penelitian populasi. Berdasarkan hal tersebut, penelitian ini adalah semua populasi dari seluruh siswa kelas VA dan VB SDN Karangbanyu 01 yang berjumlah 61 siswa.

Dalam penelitian ini menggunakan Nonprobability Sampling adalah teknik pengambilan sampel yang tidak memberikan peluang yang sama populasi. (Sugiyono,2011c;82). Salah satu macam teknik Nonprobability Sampling yang digunakan peneliti adalah teknik Sampling Jenuh dimana teknik pengambilan sampel secara keseluruhan. Jadi semua anggota populasi diambil sebagai sampel untuk memperoleh data.

\section{Teknik Pengumpulan Data}

Teknik pengumpulan data dapat dilaksankan dengan beberapa cara yaitu observasi wawancara, dan dokumentasi. Teknik pengumpulan data yang digunakan peneliti adalah sebagai berikut :

a. Tes

Tes dilakukan untuk semua kelas sampel dengan perlakuan item tes yang sama, yaitu pretest dan post-test. Pretest dipakai untuk mengukur siswa seberapa jauh memiliki kemampuan mengenai hal-hal yang akan dipelajari dalam proses pembelajaran, sedangkan Posttest dipakai untuk mengukur keadaan siswa apakah menguasai kemampuan tertentu sesuai dengan yang diinginkan.

b. Non Tes

1) Wawancara

Merupakan metode pengumpulan data yaitu dengan cara bertanya secara sepihak yang dilakukan sistematis dan berdasarkan tujuan penelitian. Dengan penggunaan wawancara ini dapat diperoleh data sistem pengajaran dan usaha untuk mengembangkan penggunaan media Teka-Teki Silang (TTS) dalam proses pembelajaran IPS kelas V di SDN Karangbanyu 03 Tahun Ajaran 2018/2019.

2) Observasi

Observasi merupakan suatu proses yang kompleks, yaitu proses yang tersusun dari berbagai proses biologis maupun psikologis. Dua diantara yang terpenting adalah proses-proses pengamatan serta ingatan. Jadi dalam observasi ini tidak terbatas pada orang akan tetapi juga obyek-obyek alam yang lain. Dalam penelitian ini peneliti membuat lembar observasi guru dan siswa melalui proses belajar mengajar.

3) Dokumentasi

Dari sinilah penulis akan mendapatkan informasi mengenai profil sekolah, keadaan, letak strategis sekolah, proses pembelajaran dan juga berbagai permasalahan yang terjadi pada proses pembelajaran berupa gambar.

\section{Instrumen Penelitian}

Sebenarnya banyak sekali intstrumen penelitian yang dapat dipakai untuk mengumpulkan informasi yang kita butuhkan. Sugiyono ( 2011d, ;102) menyatakan bahwa instrument penelitian merupakan alat yang dipakai untuk mengukur kejadian alam maupun sosial yang telah diamati. Secara terperinci semua kejadian yang diamati ini disebut variable penelitian. Kesimpulannya bahwa instrument penelitian adalah mencari informasi lengkap mengenai permasalahan baik kejadian alam maupun sosial. Dalam penelitian ini, ada 3 macam instrumen penelitian yaitu observasi, wawancara dan tes (pretest dan post-test). Observasi dilakukan untuk mengetahui aktifitas 
pembelajaran sedangkan wawancara mengetahui informasi pembelajaran IPS. Sedangkan tes dijadikan acuan untuk mengetahui tingkat pemahaman siswa dengan mengerjakan soal-soal pretest dan post-test mata pelajaran IPS dengan bentuk soal pilihan ganda.

Bentuk tipe soal yang dipakai peneliti adalah item pilihan ganda yang berjumlah 20 . Tes ini diberikan sesudah dan sebelum menggunakan media Teka-Teki Silang (TTS). Tes yang diberikan untuk mengukur kompetensi kognitif siswa. namun sebelum membuat instrumen tersebut, peneliti terlebih dahulu harus membuat kisi-kisi instrumen yang dibuat untuk mengacu pada indikator-indikator pada materi Penjajahan Belanda dan Jepang. Kisi-kisi dibuat sebanyak 4 indikator dan 20 soal.

Adapun uji persyaratan instrument adalah sebagai berikut:

a. Uji validitas

Uji validitas media pembelajaran, sebaiknya melakukan konsultasi terlebih dahulu dan meminta pertimbangan terhadap guru kelas atau guru mata pelajaran IPS. Apakah media tersebut sesuai dengan materi atau tidak. Setelah dikonsultasikan dan sudah dilakukan perbaikan pada media maka dapat dikatakan media pembelajaran yang akan kita gunakan itu valid dan layak untuk digunakan. "Validitas berasal dari bahasa inggris validity yang berarti keabsahan" ( M. Toha Anggoro, dkk., 2011c; 5.28). Pengujian validitas dapat dilakukan memakai cara menggunakan kisi-kisi instrument penelitian. Sedangkan Durri Andriani, dkk ( 2011a, ;5.28)menyatakan bahwa "aspek validitas yang penting adalah ketepatan dan ketelitian".

Untuk mengetahui ketepatan dalam pengukuran validitas, peneliti menggunakan teknik yaitu korelasi point biserial dengan menggunakan rumus :

$$
Y_{p b s}=\frac{M p-M t}{S t} \sqrt{ } \frac{p}{q}
$$

Keterangan :

$Y_{p b s} \quad=$ angka indeks korelasi point biserial

$\mathrm{Mp} \quad$ = rata-rata skor subyek yang menjawab benar

Mt = rata-rata skor total

St $=$ standard deviasi dari skor total

$\mathrm{p} \quad=$ siswa yang menjawab benar

$\mathrm{q}=$ siswa yang menjawab salah

\section{b. Uji Reliabilitas}

Uji Reabilitas dikatakan dipercaya apabila dapat diperoleh hasil yang tetap apabila digunakan dalam tes secara berkali-kali. "Reliabilitas berasal dari kata reliability yang berarti kemantapan suatu alat ukur. Jika alat ukur tersebut digunakan untuk melakukan pengukuran secara berulang kali maka alat tersebut tetapmemberikan hasil yang sama" ( M. Toha Anggoro, dkk., 2011d; 5.31). Menurut Durri Andriani, dkk (2011b, ;5.30) menyatakan bahwa ada "tiga aspek penting dalam reliabilitas adalah: dapat diandalkan (dependability), dapat diramalkan (predictable ), dan menunjukkan ketepatan". Pada dasarnya uji reliabilitas diperlukan untuk menunjukkan ketetapan dan kemantapan suatu penelitian.

Untuk menguji reliabilitas prestasi belajar siswa ini, pada penelitian tersebut memakai rumus KR 20 yaitu :

$\boldsymbol{R}_{11}=\left(\frac{n}{n-1}\right)\left(\frac{s^{2}-\Sigma p q}{s^{2}}\right)$

Keterangan :

$\mathrm{R}_{11} \quad$ : nilai reliabilitass

$S^{2} \quad$ : varians

$S \quad$ : standar deviasi tes

$\sum p q \quad$ : jumlah perkalian $\mathrm{p}$ dan $\mathrm{q}$ 
$\mathrm{p}$ :perbandingan jumlah siswa menjawab benar atau salah.

q:perbandingan jumlah siswa menjawab salah dibandingkan item soal.

$\mathrm{n}$ :banyaknya item yang d jawab

\section{Teknik Analisis Data}

"Teknik analisis data yaitu mengelompokkan data berdasarkan variabel dan jenis responden, mentabulasi data berdasarkan variabel dari seluruh responden". (Sugiyono, 2011e; 147). Dalam penelitian ini peneliti menggunakan "teknik analisis inferensial yaitu teknik pengolahan data yang memungkinkan peneliti untuk menarik kesimpulan, berdasarkan hasil penelitiannya pada sejumlah sampel, terhadap suatu populasi yang lebih besar" ( M.Toha Anggoro,dkk., 2011d; 6.14). Teknik ini juga bisa disebut juga teknik analisis uji hipotesis, karena kesimpulan yang dibuat biasanya dinyatakan dalam suatu hipotesis. Untuk menguji lebih lanjut dibutuhkan beberapa uji statistik diantaranya yaitu :

a. Uji Homogenitas

Uji ini adalah suatu prosedur yang dilakukan untuk menunjukkan dua atau lebih kelompok data sampel yang berasal dari populasi yang memiliki varian sama. (Yulingga, 2017a; 58). Proses pengujian dilakukan dengan SPSS.16 for Windows .

b. Uji Normalitas data

Uji ini digunakan untuk mengetahui apakah data suatu penelitian yang diperoleh terdistribusi normal atau tidak. "Dasar pengambilan keputusan adalah jika nilai $\mathrm{L}_{\text {hitung }}>\mathrm{L}_{\text {tabel }}$ maka Ho ditolak dan jika nilai $\mathrm{L}_{\text {hitung }}<\mathrm{L}_{\text {tabel }}$ maka Ho diterima". (Muwarni, 2001; 20) dalam (Yulingga, 2017b; 68). Pengujian normalitas data dalam penelitian ini menggunakan bantuan SPSS.16 for Windows.

c. Uji T

Uji T dengan memakai jenis Uji T ( $t$-Test) Dua Sampel. “digunakan untuk melakukan uji komparasi antara dua kondisi ( masalah ) degan catatan datanya berskala interval/ rasio".( Yulingga, 2017; 109). Dalam pengujian uji $t$ ini peneliti menggunakan SPSS.16 for Windows.

\section{HASIL DAN PEMBAHASAN}

Pada penelitian ini yang menjadi tujuaanya adalah untuk dapat mengetahui adanya pengaruh penggunaan media Teka-Teki Silang (TTS) terhadap prestasi belajar siswa kelas 5A dan 5C SDN Karangbanyu 03. Penelitian ini termasuk kedalam penelitian eksperimen.

Prosedur utama peneliti adalah terlebih dahulu meminta ijin kepada pihak sekolah bahwasannya akan mengadakan penelitian di SDN Karangbanyu 03. Pada tanggal 31 Januari peneliti menyerahkan surat perizinan penelitian kepada Kepala Sekolah SDN Karangbanyu 03. Setelah menjelaskan maksud dan tujuannya, Kepala Sekolah menyerahkan peneliti kepada guru kelas. Peneliti diberi kesempatan melakukan penelitian di kelas 5A dan 5C sebagai sampel penelitian.

Setelah itu peneliti melakukan koordinasi kepada wali kelas 5A dan 5C terkait materi yang akan dijadikan penelitian serta penentuan tanggal pelaksanaannya. Penelitian terlaksana mulai tanggal 31 Maret- 28 April 2019 terlampir ). Penelitian dimulai dengan adanya pemberian materi terlebih dahulu, untuk kelas VA (eksperimen) diberikan perlakuan memakai media Teka-Teki Silang (TTS) sedangkan untuk kelas VC (kontrol) tidak diberi perlakuan dengan menggunakan media akan tetapi dengan penjelasan materi.

Penelitian ini mengambil populasi seluruh siswa. peneliti mengambil sampel sebanyak dua kelas yaitu kelas VA (eksperimen) sebanyak 33 siswa dan kelas VC (kontrol) sebanyak 38 siswa. Dalam pengambilan data peneliti melakukan beberapa teknik yaitu, Non Tes dan Tes. Tes yang diberikan berupa Pretest dan Post-test. Pretest merupakan tes yang diberikan 
kepada kelas kontrol maupun kelas eksperimen sebelum melakukan perlakuan.

Selajutnya Post-tets itu adaklah tes yang diberikan pada proses pembelajaran kepada baik kelas kontrol maupun kelas eksperimen setelah melakukan perlakuan yaitu penggunaan media pembelajaran Teka-Teki Silang (TTS). Pelaksanaan penelitian dilakukan dengan 3 kali di kelas control ataupun kelas ekseperimen yang disesuaikan dengan Rencana Pelaksanaan Pembelajaran (RPP) yang telah jadi.

Penelitian ini memakai instrument soal pilihan ganda jumlah 20 soal dengan 4 pilihan jawaban. Soal tersebut diujikan terlebih dahulu di kelas kontrol yaitu kelas 5C yang telah mendapatkan materi Penjajahan Belanda dan Jepang. Soal ini akan diuji terlebih dahulu valid atau tidaknya item tes. Berdasarkan hasil uji coba item soal yang telah dilakukan pada jumlah peserta uji coba, $\mathrm{N}=20$ dan taraf signifikan $5 \%$ di dapat $\mathrm{r}_{\text {tabel }}=0,444$, jadi item soal dikatakan valid jika $\mathrm{r}_{\text {hitung }}>0,444$ ( $\mathrm{r}_{\text {hitung }}$ lebih besar dari 0,444). hasil uji validitas menyatakan bahwa $\mathrm{r}_{\text {hitung }}>0,444$ yang berjumlah 15 soal. Sedangkan 5 soal dinyatakan tidak valid karena $\mathbf{r}_{\text {hitung }}<0,444$. Soal valid yang berjumlah 15 soal tersebut akan dipakai sebagai soal post-test baik kelas eksperimen mapun kelas kontrol. Hasil perhitungan koefisien reliabilitas 15 soal diperoleh nilai $\mathbf{r}_{11}=0,6889$.

Untuk soal yang bervariabel, karena nilai korelasi tersebut berada pada interval 0,600 0,799 termasuk ke dalam kriteria tinggi. . Dapat diketahui bahwa nilai pretest adalah $0.063>$ 0.05 , maka data berdistribusi homogen. Dapat diketahui juga bahwa nilai signifikan nilai pretest yaitu $0,063>0,05$ dan nilai signifikansi nilai posttest yaitu 0,531>0,05 maka kesimpulannya bahwa kedua kelas tersebut adalah homogen. untuk hasil nilai pretest kelas VA dan VC adalah 0,377 dan 0,287>0,05. Sedangkan hasil nilai posttest kelas VA dan VC adalah 0,253 dan 0,269>0,05. Dari hasil diatas dapat diketahui bahwa hasil pretest maupun posttest kedua data lebih besar dari taraf signifikansi 0,05 maka data berdistribusi normal. Maka dapat disimpulkan bahwa media Teka-Teki Silang dapat memberikan pengaruh terhadap prestasi belajar IPS siswa kelas V SDN Karangbanyu 03 Tahun Ajaran 2019/2020.

\section{PENUTUP}

\section{Simpulan}

Dari hasil peneliian terdapat penulis menyimpulkan bahwa :

1. Penerapan Penggunaan media Teka-Teki Silang (TTS) menggunakan dua cara, yaitu secara individu dan kelompok. Penggunaan media ini sangat efektif untuk melatih konsentrasi siswa. Dengan mengisi kotakkotak sesuai dengan jawaban dari pertanyaan yang telah disediakan dapat menghasilkan daya ingat yang tajam dan tingkat pemahaman siswa yang lebih. Sehingga nilai prestasi belajar IPS siswa meningkat.

2. Ada pengaruh penggunaan media Teka-Teki Silang (TTS) terhadap prestasi belajar IPS siswa kelas V SDN Karangbanyu 03 Tahun Ajaran 2019/2020.

\section{Saran}

Saran-saran yang diberikan peneliti adalah sebagai berikut :

1. Untuk sekolah

Berdasarkan hasil dari penelitian ini dalam kegiatan belajar mengajar di kelas disarankan agar menggunakan media pembelajaran. Bahkan media pembelajaran tidak harus yang mahal bahkan bisa diciptakan dengan kesederhanaan bentuk namun memiliki manfaat lebih dalam mempengaruhi tingkat pemahaman siswa

\section{Untuk Pendidik}

Dimaksudkan pendidik dapat menerapkan penggunaan media terhadap mata pelajaran lain. Karena pembuatan media ini berasal dari materi pelajaran yang akan disampaikan. 
3. Untuk Peserta didik

Agar siswa lebih dapat memahami dengan baik materi pelajaran. Selain itu dapat termotivasi dalam kegiatan belajar-mengajar serta mendapatkan suasana baru yang lebih menyenangkan.

4. Untuk peneliti selanjutnya

Para peneliti selanjutnya diharapkan mampu memperbaiki kekurangan-kekurangan media Teka-Teki Silang (TTS) agar proses belajar mengajar dapat mencapai tujuan yang diinginkan.

\section{DAFTAR PUSTAKA}

Adib, Fauzan,dkk.(2016). "Upaya Peningkatan Prestasi Belajar Siswa dengan Disiplin Kerja Guru".Jurnal Pendidikan Manajemen Perkantoran.Vol.1 No.1.

Agung, Wahyu. (2010). Panduan SPSS 17.0. Jogjakarta: Garailmu.

Andriani, Durri. (2011). Metode Penelitian.Jakarta: Universitas Terbuka.

Anggoro, M. Toha. (2011). Metode Penelitian.Jakarta: Universitas Terbuka.

Hanif, Yulingga N, dkk. (2017). STATISTIK PENDIDIKAN. Sleman: CV Budi Utama.

Marisa,dkk. (2013). Komputer dan Media Pembelajaran.Tangerang Selatan: Universitas Terbuka.

Mustamin, St.Hasmiah,dkk.(2013). "FaktorFaktor yang Mempengaruhi Prestasi Belajar Mahasiswa Jurusan Pendidikan Matematika Fakultas Tarbiyah dan Keguruan UIN Alauddin Makassar".Jurnal Pendidikan Matematika dan Pembelajaran (MAPAN) .Vol. 1 No. 1.

Putri, Maya. (2016). Pengaruh Model Pembelajaran Kooperatif Tipe Picture and Picture Terhadap Hasil Belajar IPS Siswa Kelas IV SD Negeri 1 RajaBasa Raya Bandar Lampung Tahun Ajaran 2015/2016.Bandar Lampung.Tidak di publikasikan.
Sanaky, Hujair A.H. (2013). Media Pembelajaran Interaktif-Inovatif. Yogyakarta: Kaukaba Dipantara.

Sholihah, Hanifah Nur.(2015).Penggunaan Media Teka-Teki Silang untuk Meningkatkan Kosakata Bahasa Arab Siswa Kelas $V$ Madrasah Ibtidaiyah Nahdlatul Ulama'(MINU)Maudlu'ul Pandean Malang.Malang.Tidak di publikasikan.

Sholihah, Nur Marhida S.(2016).Pengaruh Media Teka-Teki Silang (Crossword Puzzle) dalam Meningkatkan Kemampuan Menghafal Kosakata Bahasa Jawa Krama pada Siswa Madrasah Ibtidaiyah (MI) Al Anwar Nangsri Bantul Kelas III, IV dan V.Yogyakarta.Tidak di publikasikan.

Sri Haryati (2017). "Pengaruh Metode Pembelajaran Croosword Puzzle Terhadap Hasil Belajar Siswa Pada Mata Pelajaran IPS Kelas VII SMP Bukit Raya Pekanbaru". Jurnal Pendidikan Ekonomi Akuntansi, Pendidikan Akuntansi FKIP Universitas Islam Riau. Vol. 5 No. 1.

Sugiyono.(2011).Metode Penelitian Kuantitatif, Kualitatif, dan $R \&$ D . Bandung:Alfabeta

Sundayana, Rostina. (2015). Media dan Alat Peraga dalam Pembelajaran Matematika. Bandung: Anggota Ikatan Penerbit Indonesia(IKAPI).

Susanto, Ahmad. (2013). Teori Belajar dan Pembelajaran. Jakarta: Prenada Media Group.

Wijayani, Isnaini.(2017).Hubungan Motivasi Belajar dengan Prestasi Belajar Siswa Kelas V SD Negeri 1 Waringinsari Barat Kabupaten Pringsewu.Bandar Lampung.Tidak di publikasikan.

Yuzarion.(2017). "Faktor Yang Mempengaruhi Pretasi Belajar Peserta Didik". .Jurnal Ilmu Pendidikan.Vol 2 No. 1,2017. 